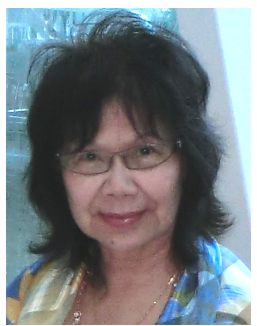

\title{
A SURVEY OF ASEAN INSTRUMENTS RELATING TO PEATLANDS, MANGROVES AND OTHER WETLANDS: THE REDD + CONTEXT
}

\author{
Koh Kheng-Lian \\ Director, APCEL \\ Emeritus Professor \\ Faculty of Law \\ National University of Singapore
}

Since the $13^{\text {th }}$ Association of Southeast Asian Nations (ASEAN) Summit in November $2007,{ }^{1}$ held in Singapore, ASEAN has accelerated its response to climate change issues, ${ }^{2}$ including REDD+ as a mechanism for climate change mitigation and adaptation, and to enhance conservation and sustainable use of natural resources. There are many wetlands in ASEAN including more than 25 million ha of peatlands spread over Indonesia, Malaysia, Thailand, Brunei, Philippines, Vietnam and Lao PDR. ${ }^{3}$ The peatlands account for 60 per cent of global tropical peatland resources. They are of significance for sequestration of carbon. However, degraded wetlands, including peatlands, are also a major source of greenhouse gases contributing to global warming. Of the types of wetlands, ASEAN has focused attention predominantly on peatlands in relation to REDD+, mainly because of the 'Indonesian Haze'.

The Asia-Pacific Centre for Environmental Law (APCEL) organised a Workshop titled, REDD+ and Legal Regimes of Mangroves, Peatland and Other Wetlands: ASEAN and the World, in Singapore from 15-16 November 2012. The articles contained in this special themed edition of the International Journal of Rural Law and Policy (IJRLP) contains a selection of the papers presented. This editorial will provide a brief background to some aspects of REDD+. Included in this issue of IJRLP is a summary of the proceedings of the workshop as interpreted by the assigned rapporteur and editors of APCEL. ${ }^{4}$ These summaries were reviewed and approved by the presenters.

\section{ASEAN common position on REDD and REDD+}

ASEAN has issued two common positions on REDD and REDD+, the latter is built upon the former.

\section{ASEAN common position papers on REDD in developing countries. ${ }^{5}$}

Soon after the establishment of the REDD+ mechanism in COP-13 (Bali Action Plan), ${ }^{6}$ ASEAN adopted the first of two documents on REDD: the ASEAN Common Position Paper ('REDD CP') in 2008. The paper

\footnotetext{
Speeches by Singapore Leaders (Embassy of the Republic of Singapore, 19 November 2007)

<http://www.mfa.gov.sg/content/mfa/overseasmission/manila/press_statements_speeches/speeches_by_sg_lead er/2007/200711/press_200711.html>.

2 ASEAN Declaration on the $13^{\text {th }}$ Session of the Conference of Parties (COP-13) to the UN Framework Convention on Climate Change (UNFCCC) and the $3^{\text {rd }}$ Session of the Conference of the Parties Serving as the Meeting of the Parties (CMP) to the Kyoto Protocol (20 Nov 2007) <http://www.asean.org/asean/asean-summit/item/aseandeclaration-on-the-13th-session-of-the-conference-of-parties-cop-to-the-un-framework-convention-on-climatechange-unfccc-and-the-3rd-session-of-the-conference-of-the-parties-serving-as-the-meeting-of-the-parties-cmp-tothe-kyoto-protocol-singapore-2>; Singapore Declaration on Climate Change, Energy and the Environment (21 Nov 2007) <http: / /www.mofa.go.jp/region/asia-paci/eas/dec0711.pdf; ASEAN Declaration on Environmental Sustainability (2007)> and <http://cil.nus.edu.sg/2007/2007-asean-declaration-on-environmental-sustainability-signed-on20-november-2007-in-singapore-by-the-heads-of-stategovernment/>; ASEAN Leaders' Statement on Joint Response to Climate Change (9 April 2010) <http://cil.nus.edu.sg/2010/2010-asean-leaders-statement-on-joint-response-toclimate-change/>; ASEAN Leaders' Statement on Climate Change to the $17^{\text {th }}$ Session of the Conference of the Parties to the United Nations Framework Convention on Climate Change (UNFCCC); $17^{\text {th }}$ Session of the Conference of Parties Serving as the Meeting of Parties to the Kyoto Protocol (17 Nov 2011)

<http://www.asean.org/archive/documents/19th\%20summit/ASEAN_Leaders' Statement_on_Climate_Change.pdf>.

3 ASEAN, 'ASEAN Peatland Forests Project - Sustainable Management of Peatland Forests in Southeast Asia' (Workshop on Enhancing Sustainability of Forestry Practices on Peatlands (WESFPP), 27-28 June 2012) $<$ www.aseanpeat.net/view_file.cfm?fileid=175> ('Apfp-SEApeat').

4 Loveleen Bhullar, Koh Kheng Lian and Lye Lin-Heng (eds), 'Summary Proceedings - Workshop on REDD+ and Legal Regimes of Mangroves, Peatlands and Other Wetlands: ASEAN and the World' (2013) [special edition] International Journal or Rural Law and Policy <http://epress.lib.uts.edu.au/journals/index.php/ijrlp>.

5 ASEAN, ASEAN Common Position Paper on Reducing Emission from Deforestation and Forest Degradation (REDD) in Developing Countries (REDD, 2008)

<http://unfccc.int/files/kyoto_protocol/application/pdf/indonesiaaseanredd060608.pdf>. ('REDD CP')
} 
resulted from the Inaugural Workshop on the ASEAN Regional Knowledge Network on Forests and Climate Change, held in Jakarta on 30-31 October 2008, and aimed to consolidate efforts taken and to negotiate further processes, including policy approaches and positive incentives for REDDs. REDD CP also includes measures for effectiveness of the method for demonstrating emission reduction from deforestation and forest degradation, and enhancement of carbon stocks.

A key consideration in this REDD CP includes a Work Plan for Strengthening Forest Law Enforcement and Governance (2008-2015), ${ }^{7}$ developing a regional framework for a Pan ASEAN Certification Initiative, Regional Action Plan on the Trade of Wild Fauna and Flora (2005-2010) and the Strategic Plan of Actions of the Heart of Borneo Initiative $(\mathrm{HoB}),{ }^{8}$ discussed later. $\mathrm{HoB}$, although not an ASEAN Initiative, is endorsed by ASEAN. It aims to protect the largest peatland in Brunei, with some peats nine metres deep in Kuala Balai.

Land Use and Land Use Change and Forestry (LULUCF) ${ }^{9}$ have contributed to global emissions including in ASEAN. The Clean Development mechanism CDM, ${ }^{10}$ which aims at mitigating emissions through a forestation/reforestation activities, is too narrow and complicated, and has prevented successful participation by ASEAN in the mechanism.

The main elements of ASEAN's REDD CP are:

- The method for defining the baseline or Reference Emission Level (REL) should be open to approaches that are additional to those based on historical emissions. Due to the erratic nature and scarcity of historical data on emissions in the ASEAN Member States (AMS), each country should be allowed to use an approach that best suits its national circumstances and capacity, with some common parameters between different approaches. Methods should be based on effectiveness in demonstrating emissions reduction from deforestation and forest degradation, including conservation and sustainable forest management practices in greenhouse gas (GHG) inventories.

- Policy approaches should also be left open for a range of REDD mitigation and forest degradation activities, including sustainable forest management, conservation and enhancement of carbon stocks.

- Positive incentives should be diversified and not limited to market-bases but include fund-based incentives.

- Coverage or readiness activities under other related financial supports, for example Climate Investment Fund and Forestry Investment Program, should be expanded to include improved forest management, conservation and enhancement of carbon stocks through sustainable forest management (SFM).

- Annex I of the UNFCCC countries should include methods to build capacity for developing countries to improve forest protection infrastructure as well as means for the transfer of technology and exchange of knowledge in this area. ${ }^{11}$

\section{REDD+ in developing countries ${ }^{12}$}

In 2010, ASEAN adopted another key instrument - this time the Common Position on REDD+, which builds on the 2008 REDD position. It sets out a number of key considerations:

- The roles of forests in biodiversity conservation, watershed protection, livelihood for forestdependent people and providing the backbone of socio-economic development in many developing countries, as well as in climate change mitigation and adaptation.

Bali Action Plan <http://unfccc.int/files/meetings/cop_13/application/pdf/cp_bali_action.pdf>.

IUCN, Proposed Work Plan for Strengthening Forest Law Enforcement and Governance (FLEG) in ASEA 2008-2015 (Agreed by the $11^{\text {th }}$ ASOF Meeting, Kuala Lumpur, 31 July - 1 August 2008). <http://cmsdata.iucn.org/downloads/ appendix_2_b_proposed_work_plan_for_strengthening_fleg_in_asean.pdf>

8 Sabah Forestry Department and WWF-Malaysia, Strategic Plan of Action (Sabah): The Heart of Borneo Initiative (Sabah Forestry Department, October 2009)

<http://www.hobgreeneconomy.org/downloads/sabah_plan_of_action_heartofborneo.pdf>

9 UNFCCC, 'Land Use, Land-Use Change and Forestry' (LULUCF) <http://unfccc.int/methods_and_science/lulucf/items/3060.php>.

${ }^{10}$ Clean Development Mechanism (CDM) is one of the flexibility mechanisms defined in the Kyoto Protocol. It provides for emissions reduction projects which generate units that may be traded.

${ }^{11}$ REDD CP, above $\mathrm{n} 5$.

${ }^{12}$ Nature and Poverty, ASEAN Common Position Paper on Reducing Emissions from Deforestation and Forest Degradation Plus (REDD+) in Developing Countries (November 2010) <http://www. natureandpoverty.net/nc/coderedd/find/docshow/asean_common_position_paper_on_reducing_emissions_from_deforestation_and_forest_degrad ation_plus_re/>. 
- Tropical forests have high carbon stock and great potential for $\mathrm{CO} 2$ sequestration.

- Risks of climate change to forest ecosystems and forest-dependent people as well as reduction in the provision of forest products and services.

- Forests may contribute significantly to climate change mitigation and adaptation.

- Adaptation measures to protect these forests from the adverse impact of climate change must be supported with capacity building, technology transfer and development, and finance.

- Reducing emissions from deforestation and forest degradation, conservation of forest carbon stocks, sustainable management of forest, and enhancing forest carbon stocks (REDD+) are the most effective tools for strengthening international cooperation on forestry in response to climate change.

- The need for collaborative efforts by the international community - including by developed countries as well as through south-south cooperation - to foster the development of REDD+ through adoption of practical and enabling financing mechanisms.

The position paper also sets out a number of key issues

- The need for a shared vision on setting targets for deep cuts of the global GHGs emissions to levels that will keep global temperature increases to below $2^{0} \mathrm{C}$.

- The limited commitment of developed countries in reducing their GHGs emissions.

- That the success of mitigation actions by developing countries, including REDD+, requires substantial financial, capacity building, and technology development and transfer support from developed countries.

- Elements for Decision on REDD+ in COP-16.

- Balanced MRV (Measurement, Reporting and Verification) of actions by developing countries and support by developed countries.

\section{ASEAN position}

In acknowledging the crucial role of REDD+ to developing countries in helping them to reduce GHG emissions and sequest carbon, the ASEAN member states, taking into account the above principles and some key issues, recommended:

- $\quad$ All parties should endeavour to reach consensus in COP-16 13 on a balanced package of decisions between Bali Action Plan and the Kyoto Protocol, and between elements of Bali Action Plan.

- All parties should collaboratively work to reduce GHG emissions to a level that maintains temperature increases to below $2^{0} \mathrm{C}$ to prevent the adverse impacts of climate changes on the basis of common but differentiated responsibilities and respective capabilities.

- REDD+ implementation should take into account social and environmental safeguards, seek to create multiple benefits as well as ensure the rights of forest-dependent people and their meaningful engagement in the design, implementation, monitoring and evaluation of REDD+ based on national circumstances.

- For REDD + to be successful, there is a need for implementable modalities, rules and procedures.

- Progress made by countries currently implementing REDD+ activities must be acknowledged, and they must be encouraged to continue their initiatives beyond readiness. REDD+ implementation shall be in accordance with national capabilities and circumstances of developing countries, respect sovereignty, and thus allow developing countries to continue their national development while at the same time contributing to mitigation of climate change. In this regard, the position paper emphasises the importance of the following elements for a COP-16 decision on REDD+: $>$ Scope of REDD+ should be as in the Bali Action Plan that covers the following activities:

(a) reducing emissions from deforestation; (b) reducing emissions from forest degradation;

(c) conservation of forest carbon stocks; (d) sustainable management of forest; and

(e) enhancement of forest carbon stocks.

$>$ The need for flexible approaches including national accounting with sub-national implementation, and a phased approach that allows developing countries to choose the phase they start at and elements in each phase.

$>$ Developing countries should be allowed to choose fund-based, market-based or a combination of fund- and market-based sources to accommodate differing country circumstances, level of readiness, priorities and other relevant policies.

\footnotetext{
${ }^{13}$ Sixteenth meeting of the Conference of the Parties (COP-16), Cancún, Mexico 29 November-10 December 2011.
} 
> Emphasise the importance for COP-16 to mandate the Subsidiary Body for Scientific and Technological Advice (SBSTA) to address outstanding technical, methodological and other relevant issues.

- Requirement of MRV of actions by developing countries should be balanced with MRV of supports by developed countries.

\section{ASEAN peatlands instruments}

This section discusses two ASEAN peatland instruments. Both are significant in the context of Indonesian fires as data shows that about 60 per cent of smoke and haze in Southeast Asia originates from the burning of Indonesia's peatlands, which cover 10-14 per cent of Indonesian's land mass. The emphasis of the instruments is to prevent fires in peatland since fighting fires in peatlands is problematic. The instruments acknowledge that the best way to prevent fires in peatlands is to conserve them in their natural state, since they cannot be rehabilitated and their natural 'fire proof' conditions not recreated.

\section{ASEAN Peatland Management Initiative (2005): Sustainable Management of Peat- lands: Wise Use, Prevention of Fires and Rehabilitation ('APMI')}

APMI was adopted at the $20^{\text {th }}$ meeting of ASOEN ${ }^{14}$ - Haze Technical Task Force (HTTF). ${ }^{15}$ It is a contribution to the implementation of the ASEAN Agreement on Transboundary Haze Pollution ${ }^{16}$ and the ASEAN Regional Haze Action Plan ('RHAP'). ${ }^{17}$ The goal of the initiative was to promote sustainable management of peatlands in the ASEAN region through collective action and enhanced cooperation to support and sustain local livelihoods and reduce risk of fire. The objectives include the reduction of the incidence of peatland fires and support for national and local implementation activities on peatland management and fire prevention.

Proposed activities included capacity building, establishing pilot projects to test new sustainable management and fire prevention, developing a regional strategy to promote peatland management, and supporting the implementation of the RHAP and the ASEAN Agreement on Transboundary Haze Pollution.

$A P M I$ deals, inter alia, with outputs, outcomes, and, management and implementation arrangements

\section{Outputs}

- Operational mechanisms for cooperation and exchange among ASEAN members to address peatland management, fires and associated haze.

- $\quad$ An ASEAN strategy and national action plan on sustainable peatland management

- Demonstration sites for peatland rehabilitation, fire prevention, water management and community participation.

- $\quad$ Enhanced capacity of stakeholders related to peatland management, fire prevention and control.

- $\quad$ An ASEAN peat fire hazard risk assessment and fire monitoring mechanism.

Outcomes

- $\quad$ Reduction in incidence of peatland fires and associated transboundary haze and improved health and productivity of affected communities.

- Improved protection and sustainable use of water and biological resources in peatlands.

- Enhanced socio-economic wellbeing of local communities living in and around peatlands.

- Reduction in GHG emissions from peatlands and reduced vulnerability to global climate change.

\footnotetext{
${ }^{14}$ ASEAN Senior Officials on the Environment (ASEON).

${ }^{15}$ Haze Technical Task Force (HTTF), Sustainable Management of Peatlands: Wise Use, Prevention of Fires and Rehabilitation - A Contribution to the Implementation of the ASEAN Agreement on Transboundary Haze Pollution and the ASEAN Regional Haze Action Plan (adopted at the $20^{\text {th }}$ meeting of ASOEN,27-28 Feb 2003, Manila) $<$ http: / / www.aseanpeat.net/index.cfm?\&menuid=42>.

${ }^{16} 2002$ ASEAN Agreement on Transboundary Haze Pollution, signed on 10 June 2002, CIL Treaty Series, (entered into force 25 November 2003) <http://cil.nus.edu.sg/2002/2002-asean-agreement-on-transboundary-haze-pollutionsigned-on-10-june-2002-in-kuala-lumpur-malaysia/>.

${ }^{17}$ ASEAN, 1977 Regional Haze Action Plan ('RHAP'), (adopted 23 December 1997) <http://cil.nus.edu.sg/rp/pdf/1997\% 20Regional\%20Haze\%20Action\%20Plan-pdf.pdf>.
} 


\section{Management and implementation mechanism}

The ASOEN-HTTF provides oversight and policy guidance to the APMI. It will coordinate activities at the national level together with other agencies as appropriate. Some of the proposed activities are reduction of incidence of peatland fires and associated haze; support national and local level implementation activities such as fire prevention and best management practices; and develop a national strategy and cooperation mechanism to promote sustainable peatland management.

Annex 3 gives a list of specialist organisations involved. These include the ASEAN Secretariat, wetlands International - Asia Pacific, ASEAN Specialised Meteorological Centre, ASEAN Regional Centre for Biodiversity Conservation, SEA-PEAT (Southeast Asia Peatland Network), University of Palangkaraya, Indonesia Institute of Science (Indonesia) and Universiti Sains Malaysia.

\section{ASEAN Peatland Management Strategy (2006-2020) ('APMS') ${ }^{18}$}

APMS operates under the Framework of APMI. ${ }^{19}$ APMS notes that there are no specific laws or policies directly related to peatlands, but that the goals and objectives of the earlier document, APMI, are to promote sustainable management of peatlands through collective actions and enhanced cooperation to support and sustain local livelihoods, reduce risk of fires and contribute to global environmental management.

In most AMCs, there is a broad range of different ministries and agencies with some role or responsibilities related to peatland management. Nevertheless, these different ministries and agencies have common Issues and concerns:

- Peatland fire and transboundary haze pollution

- Community livelihood - causing peatland degradation

- Over-exploitation of peatland and its resources

- Drainage

- Loss of biodiversity

- Carbon loss

- Introduction of pests and diseases

- Lack of knowledge regarding peatland management

- Current legislation and policies

- Issues of definition

AMCs also have common needs regarding peatland management including improvement of knowledge of peatland ecosystem, conflict of interest between local people, industries, and government; improve scientific knowledge; improve partnerships between stakeholders; improve legislations and policies.

APMS aims to achieve the ASEAN Vision $2020^{20}$ to have 'a clean and green ASEAN ... to ensure the protection of the region's environment, the sustainability of its natural resources, and the high quality of life of its peoples'. The strategy will be a contribution to the implementation of the ASEAN Regional Haze Action Plan, and the ASEAN Regional Agreement on Transboundary Haze Pollution.

\section{(i) ASEAN Regional Haze Action Plan ('RHAP')}

The RHAP was endorsed by the ASEAN Environment Ministers in December 1997 during a period of intense fire and transboundary haze pollution. Under its overall framework, strategic measures and activities have been targeted to strengthen the region's capacity and capability to address transboundary haze pollution. The RHAP has three primary objectives: (i) to prevent land and forest fires through better management policies and enforcement; (ii) to establish operational mechanisms to monitor land and forest fires; and (iii) to strengthen regional land and forest fire-fighting capability with other mitigation measures.

The RHAP has three major components: prevention, mitigation and monitoring. Malaysia takes the lead in prevention, Indonesia in mitigation and Singapore in monitoring of fires and haze. AMCs also under-

\footnotetext{
${ }^{18} 2006$ ASEAN Petaland Management Strategy (Adopted by the Environment Ministers at the $10^{\text {th }}$ ASEAN Ministerial Meeting on the Environment, Cebu, Phillipines, 10 November 2006) $<$ haze.asean.org/docs/1245724927/APMS_whole.pdf/view>.

${ }^{20}$ ASEAN Vision 2020 (Adopted by ASEAN Heads of State/Government at the $2^{\text {nd }}$ Informal Summit, Kuala Lumpur, Malaysia, 15 December 1997) <http://cil.nus.edu.sg/rp/pdf/1997\%20ASEAN\%20Vision\%202020-pdf.pdf>.
} 
take national level actions that relate to the three RHAP components. Implementation of the RHAP at the sub-regional and regional level should complement measures taken at the national level.

\section{(ii) ASEAN Agreement on Transboundary Haze Pollution (2002)}

The landmark ASEAN Agreement on Transboundary Haze Pollution ${ }^{21}$ was signed by the ten AMCs on 10 June 2002 in Kuala Lumpur, Malaysia and came into force on 25 November 2003. It contains provisions on monitoring, assessment and prevention, technical cooperation and scientific research, mechanisms for coordination, lines of communication, and simplified customs and immigration procedures for disaster relief. The Agreement also provides for the establishment of an ASEAN Coordinating Centre for Transboundary Haze Pollution Control. To date, Brunei Darussalam, Lao PDR, Malaysia, Myanmar, Philippines, Singapore, Thailand and Viet Nam have ratified/acceded to the Agreement and deposited their instrument of ratification/approval with the ASEAN Secretariat. ${ }^{22}$

\section{The 'plus' (+) of REDD}

The scope for REDD+ goes beyond deforestation and forest degradation to include the role of conservation and sustainable management of natural resources. In the area of wetlands, ASEAN has facilitated the implementation of multilateral environmental agreements (MEAs) such as the Ramsar Convention of Wise Use of International Wetlands ('Ramsar Convention')), Convention on Biological Diversity ('CBD') and the World Heritage Convention ('WHC'). This is illustrated by the ASEAN Declaration of Heritage Parks, 2003 ('ADHP') ${ }^{23}$ where ASEAN Heritage Parks (AHPs) are synergised with the Ramsar Convention, $C B D$ and $W H C$ as in situ conservation and protected areas. The ecological networks envisaged in the $A D H P$ allows planning and management as part of the human use of landscape. This integration makes the ecological network a useful mechanism in the implementation of the CBD and the Ramsar Convention (though the latter is not mentioned in the ADHP (see Ramsar ratification and sites by ASEAN Member States in Appendix, Figure 1) in the AHPs.

ASEAN also has numerous biodiversity strategies, plans of action and programmes contained in numerous instruments including the ASEAN Socio-Cultural Community ('ASCC') Blueprint ${ }^{24}$

\section{ADHP}

The ADHP replaces an earlier ADHP and Reserves 1984 and was set up under the ASEAN Strategic Plan of Action on the Environment 1994-998 ('ASPAE'): ${ }^{25}$

Establish a regional framework on biological conservation ....

Promote the development of a framework for the protection and conservation of heritage areas

AHPs designated under the ADHP are areas with management plans in place to protect them; this is the strategies for safeguarding biodiversity and ecosystems. For example, there are a number of wetlands designated by the AHPs, eg., Singapore's Sungei Buloh Wetland Reserve and the $\mathrm{Ba}$ Be wetlands in Vietnam.

However, there is no guarantee that AHPs, some of which are or have mangroves within the designation, have a management plan, and some wetlands within AHPs are degraded. Nor is it a guarantee that the AHP will never be used for another purpose. Or, if an AHP which has a mangroves that are in a degraded state, it can have REDD+ activities such as afforestation or reforestation of the degraded mangroves.

\section{Preamble of ADHP}

Concerned with the necessity to conserve national protected areas of the ASEAN member countries;

Aware that the uniqueness, diversity and outstanding values of certain national protected areas that deserve recognition regionally and internationally;

\footnotetext{
212002 ASEAN Agreement on Transboundary Haze Pollution, above n 16.

${ }^{22}$ See L Raman, Peatlands and Climate Change: The ASEAN GEF-IFAD Peatland Project.

${ }^{23} 2003$ ASEAN Declaration on Heritage Parks, signed on 18 December 2003, CIL Treaty Series, (Adopted 18 December 2003) <http://cil.nus.edu.sg/2003/2003-asean-declaration-on-heritage-parks-signed-on-18-december-2003-inyangon-myanmar-by-the-environment-ministers/>.

${ }^{24}$ ASEAN, ASEAN Socio-Cultural Community Blueprint (2009) <http://www.asean.org/archive/5187-19.pdf>

${ }^{25} \mathrm{~K}$ L Koh (ed), ASEAN Environmental Law, Policy and Governance, Selected Documents (World Scientific, Vol 1, 2003) 713.
} 
Noting the target set by the World Summit on Sustainable Development (WSSD) 2002 of reducing the current rate of loss of biodiversity by 2010 through promoting international support and partnership for the conservation and sustainable use of biodiversity, promoting and supporting initiatives for hot spot areas and other areas essential for biodiversity and promoting the development of national and regional ecological networks and corridors;

Recognizing that conservation areas should be managed to maintain ecological processes and life support systems, preserve genetic diversity; ensure sustainable utilization of species and ecosystems; and maintain wilderness that are of scenic, cultural, educational, research, recreational and tourism values.

Objectives and criteria (AHPs) 2003

The objectives of AHPs are:

- To generate greater awareness, pride, appreciation, enjoyment and conservation of ASEAN's rich natural heritage through the creation and support for a regional network of representative protected areas.

- To generate greater collaboration between ASEAN member countries in preserving their shared natural heritage.

The criteria for AHPs under ADHP include:

- Ecological Completeness. The site must demonstrate wholesome ecological processes and must have the capability to regenerate with minimal human intervention.

- Naturalness. The area must be, for the most part, in a natural condition. It may be a second growth forest or a rescued coral reef formation, but the natural processes are still going on.

- High Conservation Importance. The site is recognised as a site of global significance for the conservation of important or valuable species, ecosystems or genetic resources; it creates or promotes awareness of the importance of nature, biodiversity and the ecological process; it evokes respect for nature whenever people see it.

- Legally Gazetted Areas. The site must be identified, boundaries defined and it must be designated by law or any legally accepted instrument of the AMCs. Its use should be primarily as a protected area.

- Approved Management Plan. The site must have a management plan duly approved by authorities of the AMC.

Additional values to be sought would include importance for endangered or precious biodiversity; the site could be habitat of importance or endangered flora or fauna.

Examples of AHP wetlands

AHPs have increased over the past few years. Currently there are some 39 and the numbers are increasing. ${ }^{26}$ Wetland areas or areas with wetlands are included.

Singapore: Sungei Buloh Wetland Reserve, $A H P^{27}$

On 1 Jan 2002, 130-ha of Sungei Buloh was officially gazetted as a nature reserve and renamed as Sungei Buloh Wetland Reserve to better reflect its status. The 130 ha reserve lies in the north-western corner of Singapore and protects one of Singapore's last remaining mangrove swamps. An extensive network of trails, viewing towers and observation hides make the reserve the perfect place to discover this fascinating ecosystem.

Ba Be National Park, AHP and Ramsar Site, Vietnam ${ }^{28}$

In 2004, Ba Be became an ASEAN Heritage Park. In 2011, it received a UNESCO certificate recognising it as Vietnam's third Ramsar site.

\footnotetext{
${ }^{26}$ Wikipedia, ASEAN Heritage Parks (26 January 2013) <http://en.wikipedia.org/wiki/ASEAN_Heritage_Parks>.

${ }^{27}$ National Parks, Sungei Buloh Wetland Reserve (2012) Singapore Government <http://www.nparks.gov.sg/cms/ index.php?option=com_visitorsguide\&task=naturereserves\&id=57\&ltemid=75>.

${ }^{28}$ Vietnam-Beauty, Ba Be National Park (2013) <http://www.vietnam-beauty.com/top-destinations/81-ba-benational-park.html>
} 


\section{Regional Action Plan for ASEAN Heritage Parks and Protected Areas (2007)}

The Regional Action Plan for ASEAN Heritage Parks and Protected Areas was the outcome of the $2^{\text {nd }}$ ASEAN Heritage Parks Conference and $4^{\text {th }}$ Regional Conference of Protected Areas in Southeast held in Kota Kinnabalu, Saba, Malaysia, 23-27 April 2007. ${ }^{29}$ It was co-organised by: ASEAN Centre for Biodiversity; IUCN-World Commission on Protected Areas; Birdlife International; WWF; Lembaga Pemegang Amanah; and UNESCO.

The objective of the Plan was to identify regional actions to meet the targets in the Durban Accord ${ }^{30}$ and to strengthen the management of the network of Protected Area Systems with a focus of AHPs.

The ASEAN Socio-Cultural Community (ASCC) Blueprint, II. D8 (iii) promoting sustainable management of natural resources calls for the promotion of further listings and a coordinated management of AHPs as an effective platform for ecosystem-based protected areas management by 2015.

\section{ASEAN's endorsement of the Heart of Borneo Declaration Initiative (2007) $(\mathrm{HOB})^{31}$}

The HoB is a transboundary protected area covering three countries; Brunei Darussalam, Indonesia and Malaysia have adopted this Declaration. It is not an ASEAN instrument but ASEAN has endorsed it. The Initiative involves strategic and operational plans which will form the basis for the development of a road map towards realising the vision of the HoB Initiative of forest management and conservation.

The $\mathrm{HoB}$ is a large and unfragmented forest covering the highlands and adjacent foothills that stretch along the borders of Brunei Darussalam, Indonesia and Malaysia. It is a rich treasure house, full of an immense variety of wild animals and plants and is the only place on the planet where the Indo-Malay forests of Southeast Asia can be conserved on a large scale.

The Kuala Balai peatswamp is one of the most extensive peatlands in Brunei and some of these peatlands have a depth of nine metres. A project is being carried out by Standard Chartered Bank to help prevent a climate-critical ecosystem in Brunei in the area. The project, 'An Action Plan for the Peatlands within the "Heart of Borneo" Area in the Context of Rehabilitating Degraded Peatlands and Reducing CO2 Emissions' commenced in October 2008 and is nearing completion. The project is jointly funded by the Foreign and Commonwealth Office of the United Kingdom and Standard Chartered Bank. The ultimate goal of the project is to lead to a reduction in $\mathrm{CO}_{2}$ emissions, fire and smog from degraded peatlands by:

- Building support and creating awareness on the wise use of peatlands and the benefits of rehabilitation of degraded peatlands;

- Developing partnerships between the three Heart of Borneo countries to share experiences and develop joint initiatives in conservation and management; and

- Identifying degraded areas to implement rehabilitation works.

\section{Ratification by AMCs of the Ramsar Convention}

Eight of the ten AMCs have ratified the Ramsar Convention: Cambodia, Indonesia, Laos, Malaysia, Myanmar, Philippines, Thailand and Vietnam. The two AMCs that have not ratified are Brunei and Singapore. ${ }^{32}$ The relevant MEAs relating to peatlands, mangroves and other wetlands are found in the following main MEAs:

\footnotetext{
${ }^{29}$ ASEAN Centre for Biodiversity, BirdLife International, Haribon Foundation, and SabahParks (2008) (Proceedings of the 2nd ASEAN Heritage Parks Conference and $4^{\text {th }}$ Regional Conference for Protected Areas, Sabah, Malaysia, 23-27 April 2007).

${ }^{30}$ IUCN, The Durban Accord (24 March 2005) <http://cmsdata.iucn.org/downloads/durbanaccorden.pdf>.

${ }^{31}$ WWF, The Heart of Borneo Declaration: Declaration on the Heart of Borneo Initiative (signed 12 February 2013) <http://wwf.panda.org/what_we_do/where_we_work/borneo_forests/borneo_rainforest_conservation/declaration .cfm>.

${ }^{32}$ See Appendix I, Table 1.
} 
For the purpose of this Convention wetlands are areas of marsh, fen, peatland or water, whether natural or artificial, permanent or temporary, with water that is static or flowing, fresh, brackish or salt, including areas of marine water the depth of which at low tide does not exceed six metres. ${ }^{33}$

It was reported: 'The ASEAN region began establishing Ramsar sites from a total of $120 \mathrm{~km}^{2}$ in 1988 to $1627 \mathrm{~km}^{2}$ in 1992. A lull in establishing new sites was experienced from 1995 to 1998, during which only a mere five $\mathrm{km}^{2}$ were additionally recognised. From 1999 to 2008, the region increased its Ramsar sites to 29 , covering a total of $13000 \mathrm{~km}^{2}, 34$

Examples of some of the Ramsar sites in ASEAN: ${ }^{35}$

- Beung Kiat Ngong Wetlands, Lao

- Danau Sentarum National Park, West Kalimantan Province, Indonesia

- $\quad$ Stung Treng, Cambodia

- $\quad$ Olango Island in Lapu, Lapu, Cebu, Philippines

In spite of the declaration of these Ramsar sites, Wetlands in the ASEAN region continue to be under extreme pressure from factors originating in human activities, with urban expansion, wetlands conversion, pollution, sedimentation and siltation being among the most common factors.

\section{ASEAN instruments relating to biodiversity including wetlands}

ASEAN has a number of plans, programmes and strategies relating to biodiversity contained in ASEPs I, II \& III, ${ }^{36}$ ASEAN Strategic Plan of Action on the Environment, ${ }^{37}$ Hanoi Plan of Action, ${ }^{38}$ Vientiane Action Programme ${ }^{39}$ and ASEAN Socio-Cultural Community Blueprint. ${ }^{40}$ The above biodiversity instruments include protection of wetlands and coastal and marine environments. ASEAN's criteria for designating marine heritage areas are similar to those of ADHP. The Hanoi Plan of Action (1999-2004) calls for the 'development of a framework to improve regional coordination for the integrated protection and management of coastal zones, development of a regional action plan for the protection of the marine environment from land-based and sea-based activities, and promote regional coordination to protect Marine Heritage Park and Reserves'. ${ }^{41}$ The Hanoi Plan of Action has now been replaced by the ASCC Blueprint, II, D7. Promoting the sustainable use of coastal and marine environment; in II. D7 (iii): 'Establish a representative network of protected areas to conserve critical habitats by 2015 through further implementation of the ASEAN Criteria for Marine Heritage Areas; ${ }^{42}$ and ASEAN Criteria for National Protected Areas'. ${ }^{43}$

Although these biodiversity areas relating to wetlands may not come within the scope of REDD+, nonetheless, an ecosystem approach to conservation must be examined from the viewpoint of 'the whole of landscape and seascape' - perhaps a REDD++ where these contribute to significant carbon sinks.

\footnotetext{
${ }^{33}$ Ramsar Convention, art 1(1) <http://www.ramsar.org/cda/en/ramsar-documents-texts-convention-on20708/main/ramsar/1-31-38\%5E20708_4000_0>.

${ }^{34} \mathrm{CHM}$, Wetland Ecosystems,

<http://chm.aseanbiodiversity.org/index.php?option=com_content\&view=article\&id=164\&ltemid=164> .

${ }^{35}$ See Appendix, Table 2.

${ }^{36}$ Koh, above $\mathrm{n} 25$.

${ }^{37}$ ASEAN Cooperation on Environment <http://environment.asean.org/index.php?page=overview:poa:spae> .

${ }^{38} \mathrm{Ha}$ Noi Plan of Action, adopted 15 December 1998, CIL <http://cil.nus.edu.sg/1998/1998-ha-noi-plan-of-actionsigned-on-15-december-1998-in-ha-noi-viet-nam-by-the-heads-of-stategovernment/>.

39 Vientiane Action Programme 2004-2010, adopted by the Heads of State/Government, $10^{\text {th }}$ ASEAN Summit $(29$ November 2004) <http: / cil.nus.edu.sg/rp/pdf/2004\%20Vientiane\%20Action\%20Programme\%202004-2010-pdf.pdf>.

${ }^{40}$ Blueprint on the ASEAN Socio-Cultural Community, adopted 1 March 2009, CIL <http://cil.nus.edu.sg/2009/2009blueprint-on-the-asean-socio-cultural-community/>.

${ }^{41} \mathrm{Ha}$ Noi Plan of Action, above n 38.

42 ASEAN Criteria for Marine Heritage Areas, adopted on 20 November 2002 in Vientiane, Laos by the Environment Ministers, <http://cil.nus.edu.sg/2002/2002-asean-criteria-for-marine-heritage-areas-adopted-on-20-november2002-in-vientiane-laos-by-the-environment-ministers/>.

43 ASEAN Criteria for National Marine Protected Areas, Adopted by the Environment Ministers at the7th Informal ASEAN Ministerial Meeting <http: / / cil.nus.edu.sg/rp/pdf/2002\%20ASEAN\%20Criteria\%20for\%20National\% 20Marine\%20Protected\%20Areas-pdf.pdf>.
} 


\section{Conclusion}

ASEAN has included REDD+ in its agenda and has formulated guidelines on peatland management in order to reduce emissions through deforestation and degradation, particularly the Indonesian haze. Much more needs to be done to bring the legal and policy frameworks of the wetlands and other relevant laws of the AMCs to align them with its common position on REDD+. ASEAN can play a more robust role in supporting and encouraging more AMCs to be ready for REDD+ by addressing many gaps that now stand in the way, such as the lack of uniform definition of forests/wetlands, policies on the right of indigenous communities to REDD+ benefits and financing mechanisms. The lack of comprehensive definition of 'forests' and 'wetlands' can lead to different policies, management problems in peatlands, mangroves and other wetlands. It is important to have harmonisation in this area in tandem with the ASEAN common position on REDD+ for negotiations at the international fora.

In the 'plus' (+) aspect of REDD, ASEAN should strengthen the management of wetlands and also ensure that they are not subsequently converted for some other uses. Perhaps the designation of more wetlands as ASEAN Heritage Parks together with the designation of Ramsar sites, wherever applicable, may deter the AMCs from land use change.

\section{APPENDIX}

Table 1: RAMSAR sites in ASEAN member countries

\begin{tabular}{|l|c|}
\hline Name & $\begin{array}{c}\text { Convention of Wetlands of International } \\
\text { Importance 1972, (RAMSAR) }\end{array}$ \\
\hline Brunei & No ratification \\
\hline Indonesia & X (1992) \\
\hline Laos & X (2010) \\
\hline Malaysia & X (1995) \\
\hline Myanmar & X (2010) \\
\hline Philippines & X (1994) \\
\hline Singapore & No ratification \\
\hline Thailand & $X(1998)$ \\
\hline Vietnam & $X(1989)$ \\
\hline Cambodia & $X(1999)$ \\
\hline
\end{tabular}

Table 2: Cambodia - three sites found, total area: 54600 hectares

\begin{tabular}{|c|c||l|c|}
\hline WI Site No. & Ramsar No. & \multicolumn{1}{|c|}{ Site Name } & Country \\
\hline \hline 2 KH001 & 997 & $\begin{array}{l}\text { Boeng Chhmar and } \\
\text { Associated River System } \\
\text { and Floodplain }\end{array}$ & CAMBODIA \\
\hline 2 KH002 & 998 & $\begin{array}{l}\text { Koh Kapik and Associated } \\
\text { Islets }\end{array}$ & CAMBODIA \\
\hline 2 KH003 & 999 & $\begin{array}{l}\text { Middle Stretches of } \\
\text { Mekong River North of } \\
\text { Stoeng Treng }\end{array}$ & CAMBODIA \\
\hline
\end{tabular}

